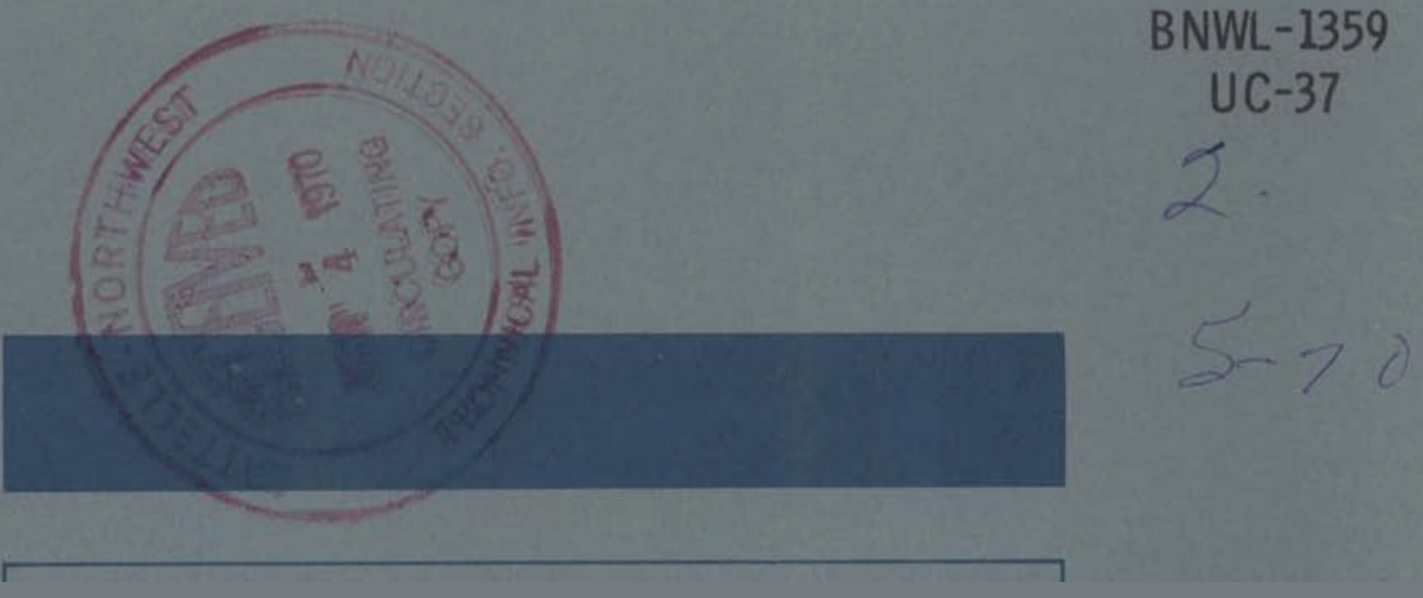

THE NONDESTRUCTIVE EXAMINATION

OF G AND H LOTS FFTF FUEL CLADDING

J. Ryden, Jr

E. F. Perrizo

May 1970

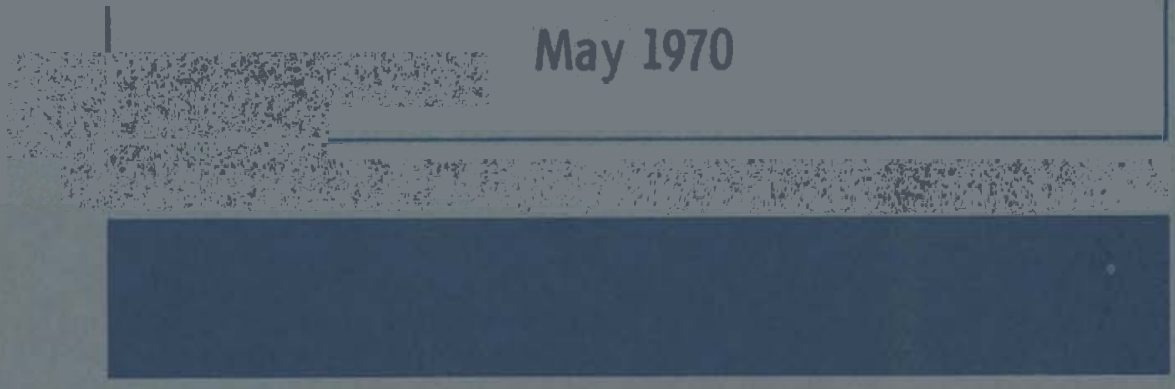

AEC RESEARCH \& DEVELOPMENT REPORT

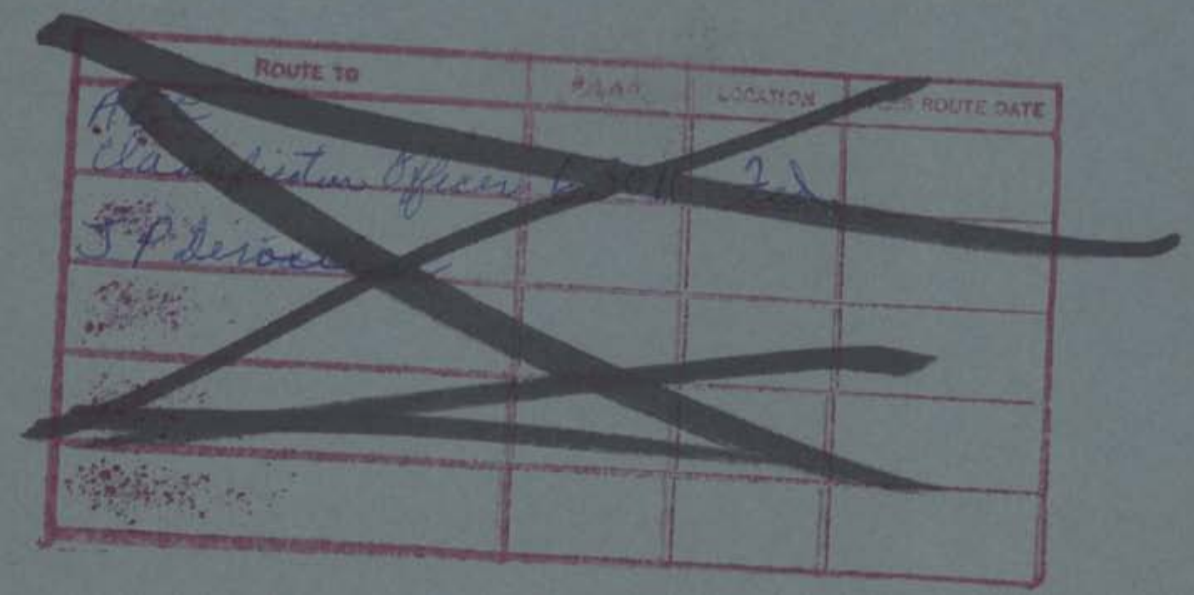

BATTELLE $\mathbf{B}$ NORTHWEST BATTELLE MEMORIAL INSTITUTE PACIFIC NOHWWUISST LABORATORIES

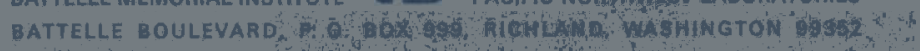




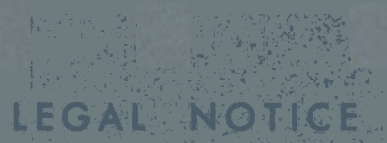

This report was prepared as an account of Government sponsored work. Neither the United States, nor the Commission, nor any person acting on befhalf of the Cominission:

in

A. Makes any warranty or representation, expressed or implied, with respect to the accuracy, conpleteness, or usefulness of the information contained, in this report, or that the use of any information, apparatus, method, or process disclosed in this report moy notsinfringe privately owned rights; or

B. Assumes any liabilities with respect. to the Us of, or for domages resulting from the use of any information, apparatus, method, or process disclosed in this report.

4. As used in the above, "person acting on behalf of the Commission" includes any employee or contractor of the Commission, or employee of such contractot to the extent that such employee or con: tractor of the Commission, or employee of such contractor prepares, disseminases, or provides access fo, ony information pursuant to his employment or" contract with the Commission, or his employment with such contracior.

\section{PACIFIC NORTHWEST LABORATORY \\ RICHLAND; WASHINGTON \\ operated by \\ BATTELLE MEMORIAL INSTITUTE}

for the

ÜNITED STATES ATOMIC ENERGY COMMISSION UNDER CONTRACT AT(45-1)-1830 


\section{THE NONDESTRUCTIVE EXAMINATION \\ OF G ANB H LOTS FFTF FUEL CLADDING}

\section{By}

J. Ryden, Jr.

E. F. Perrizo

Nondestructive Testing Department

Systems and Electronics Division

May 1970

BATTELLE MEMORIAL INSTITUTE

PACIFIC NORTHWEST LABORATORIES

RICHLAND, WASHINGTON 99352 
BNWL - 1359

Printed in the United States of America Available from

Clearinghouse for Federal Scientific and Technical Information National Bureau of Standards, U.S. Department of Commerce Springfield, Virginia 22151

Price: Printed Copy $\$ 3.00 ;$ Microfiche $\$ 0.65$ 


\title{
THE NONDESTRUCTIVE EXAMINATION \\ OF G AND H LOTS FFTF FUEL CLADDING
}

\author{
J. Ryden, Jr. \\ E. F. Perrizo
}

\section{ABSTRACT}

An inspection for defects, using ultrasonic techniques, has been performed on $2744 \mathrm{ft}$ of small diameter stainless steel tubing ( $G$ and $H$ Lots). The intended use for this tubing was as reactor fuel cladding in fuel performance studies for the Fast Flux Test Facility (FFTF).

The ultrasonic pulse-echo inspection mode was used to detect and reject defects equal to or greater than $8 \%$ of the wall thickness in depth. Statistical control techniques were used to maintain the precision of the tester to a known value. This provided a test of high reliability and a greater assurance that defects of rejectable size were actually rejected.

Although the two lots had the same metallurgical composition, they were fabricated differently. The H Lot tubes were fabricated in a conventional manner. The $G$ Lot received extra treatment and care in the fabrication in an attempt to reduce the number of rejectable defects. The test results verified that $G$ Lot did have fewer defects; i.e., $8 \%$ for $G$ Lot versus $15 \%$ for $H$ Lot. 



\section{CONTENTS}

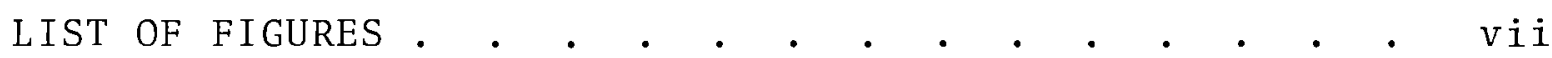

INTRODUCTION • . . . . . . . . . . . . . . 1

SUMMARY. . • . • . . . . • . . . . . . . 1

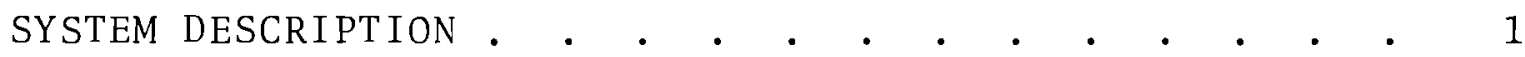

General. • • • • • . . . • • • • • . . 1

Electronics . . . . . . . . . . . . . . 3

Tubing Transport System . . . . . . . . . . 4

DESCRIPTION OF ULTRASONIC TECHNIQUE

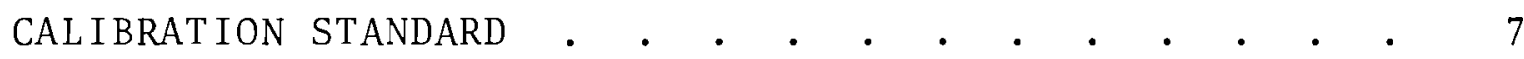

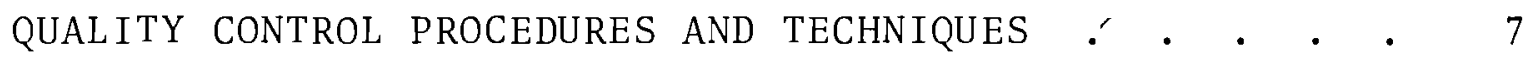

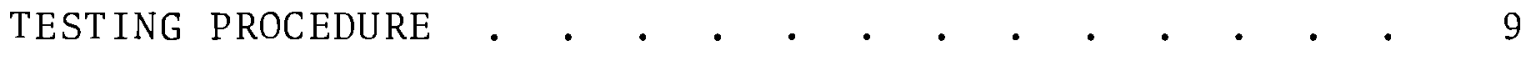

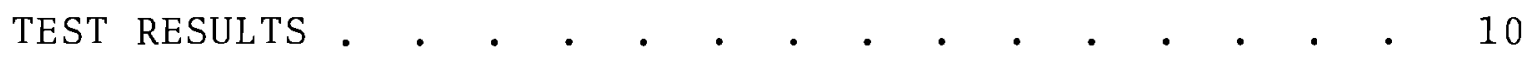

ACKNOWLEDGEMENTS . • • • • • • • • • • • • . 13

REFERENCES. • . . . . . . . . . . . . . . 13

APPENDIX A - TESTING AND CLADDING SPECIFICATIONS . . . A-1 


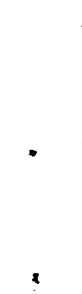




\section{LIST OF FIGURES}

1 U1trasonic Tube Testing Facility 2

2 Electronics Block Diagram 3

3 Tubing Transport System Cross Section 5

4 U1trasonic Transducer Positions 6

5 Calibration Standard Drawing and Measured Notch Depth

6 Typical Defect from G Lot 11

7 Typical Defect from $H$ Lot 12 


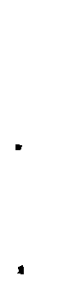




\author{
THE NONDESTRUCTIVE EXAMINATION \\ OF G AND H LOTS FFTF FUEL CLADDING \\ J. Ryden, Jr. and E. F. Perrizo
}

\title{
INTRODUCTION
}

The nondestructive examination of $G$ and $H$ Lots FFTF fuel clad tubing for defects has been performed. This report presents a description of the equipment, techniques and quality control program used, as well as test, statistical, and metallographic results. Appendix A includes testing specifications and cladding description.

\section{SUMMARY}

An ultrasonic pulse-echo technique was used to inspect $2744 \mathrm{ft}$ of FFTF developmental fuel cladding for defects. Verification and control of the tester performance was made by use of a statistical control procedure that was followed throughout the testing. The defect reject size was based on the tester responses from electric-discharge-machined (EDM) notches that were oriented both axially and circumferentially on both tube surfaces. Defects were rejected that produced tester indications equal to or greater than that obtained from 1.2 mil deep by 5 mil wide by $30 \mathrm{mil}$ long EDM notch. The test system's precision was such that there was a 0.95 certainty that the above size defects were rejected $95 \%$ of the time.

\section{SYSTEM DESCRIPTION}

GENERAL

A photograph of the complete tube testing facility is shown in Figure 1. It consists of system electronics, transducers, recorder and tubing transport system. 
BNWL -1359

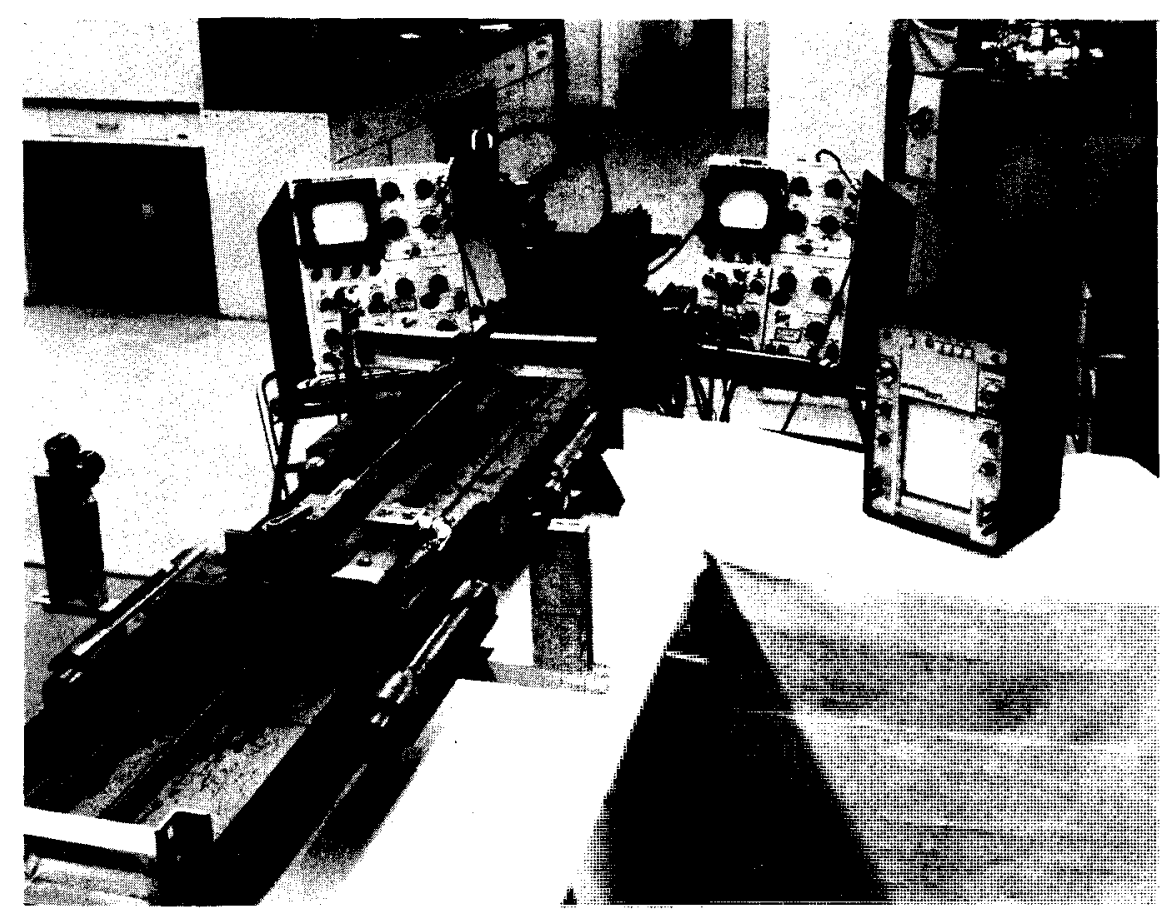

FIGURE 1. Ultrasonic Tube Testing Facility

The electronic units are built into a Tektronix Oscilloscope plug-in chassis. The oscilloscopes are used for displaying the signal train and gating pulses.

The transducers are mounted on fixtures inside the water tank. Micrometer adjustments allow the transducers to be accurately aligned to the tube surface.

The recorder has two channels and is used to record the defect responses. One channel is for the transverse defects, and the other is for the axial defects.

The transport system provides an accurate helical scan along the tube length. A synchronous motor provides a tube rotation of $1450 \mathrm{rpm}$. The water tank, containing the transducers, is translated the length of the tube by a motor driven lead screw. 


\section{ELECTRONICS}

Two modified NORTEC NDT-100 ultrasonic testers, one for each transducer, were used. The function of these units was to repetitively pulse the transducers, amplify and process the return echoes for display on a strip chart recorder. Since the basic testers consisted of only a pulser and receiver, gating and integrating circuits were designed and incorporated in the units. Figure 2 shows a block diagram of the modified unit. The operation is as follows. The pulser supplies a sharp spike pulse to the transducer at a fixed repetitive rate. The signals from the transducer are amplified by the amplifier and then displayed on the oscilloscope CRT. This same signal train is also coupled to the Flaw Gate which has two modes of operation: Direct and Surface Gate

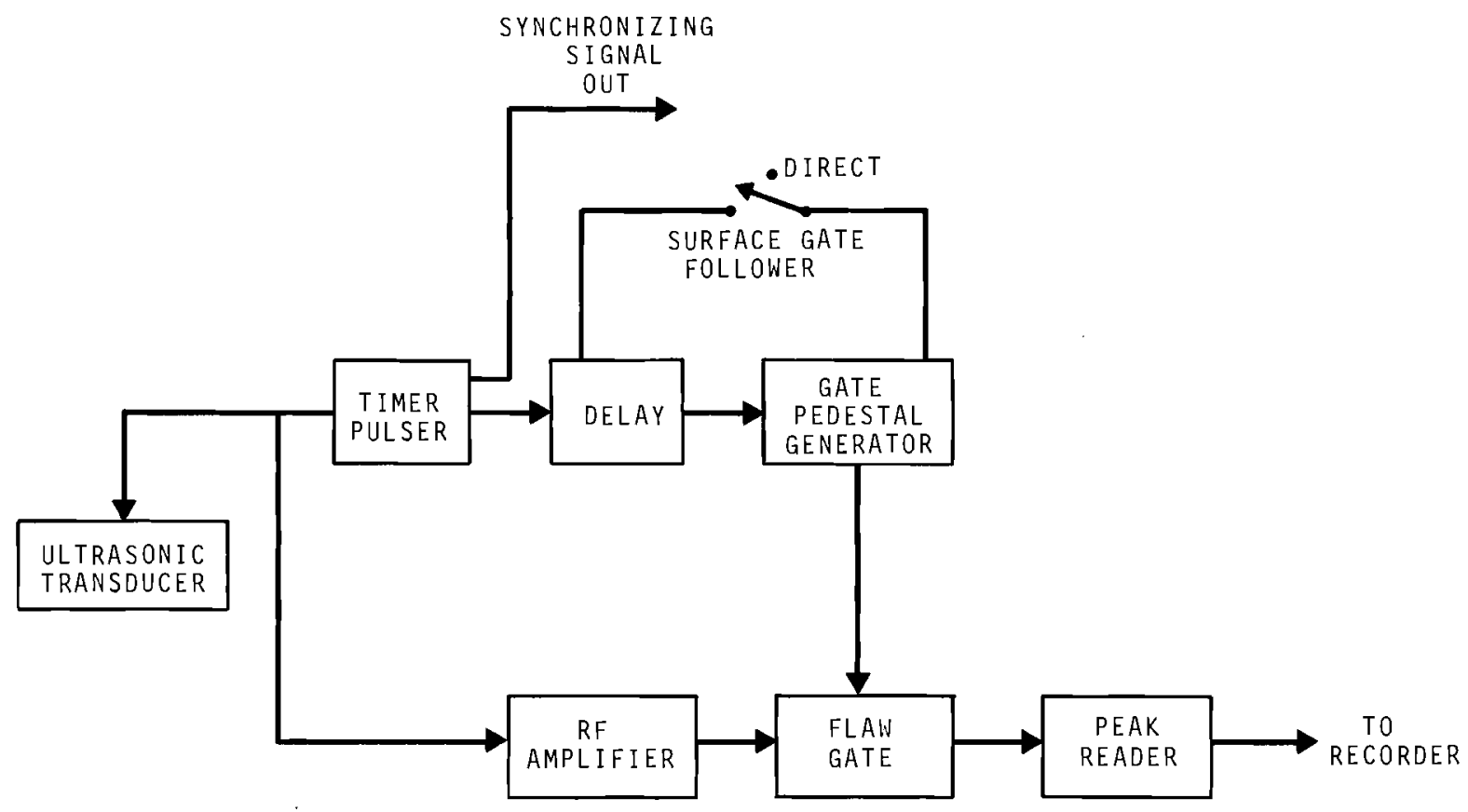

FIGURE 2. Electronics Block Diagram 
Follower. In the Direct mode, the time position of the gating pulse is fixed. In the Surface Gate Follower mode, the position of the gating pulse remains a fixed amount of time behind the front surface signal. Thus, if the tube to transducer distance varies, so will the gating pulse and the flaw signals will always occur within the gating pulse. The Delay and Gate Pedestal Generator circuits provide the necessary signals for the positioning of the flaw gate. The output of the flaw gate contains only the defect signals. This output is coupled to a peak reader circuit which processes the signals for display on a strip chart recorder.

\section{TUBING TRANSPORT SYSTEM}

The transport system provides the basic helical scan over the length required for $100 \%$ ultrasonic inspection of the tubing. The equipment, illustrated in Figure 3 , provides the test scan while accurately maintaining the required tube to transducer alignment.

With the tank at the end position, the tube to be tested is placed between the mandrels and grasped on the inside surface by expandable rubber chucks. The tubing is then rotated by a synchronous motor coupled to the mandre1. A second motor is coupled to a lead screw which drives the test tank in either direction. Entry ports at the sides of the water tank provide access for the tube being tested. Rubber "o" rings, mounted in bearings, fit snugly around the tube and contain the water. To reduce the tendency of some tubes to vibrate when rotated at $1450 \mathrm{rpm}$, tube stabilizers are mounted 18 in. apart on the main frame. The stabilizers are designed so that they open and close upon the passing of the tank. While the tubing is rotated, the test tank is translated from its start position, over one mandre1, to its finish position over the other mandre1. The tested tube is then ready to be exchanged for an untested tube. An exchange can take place in less than 60 sec. 
BNWL -1359
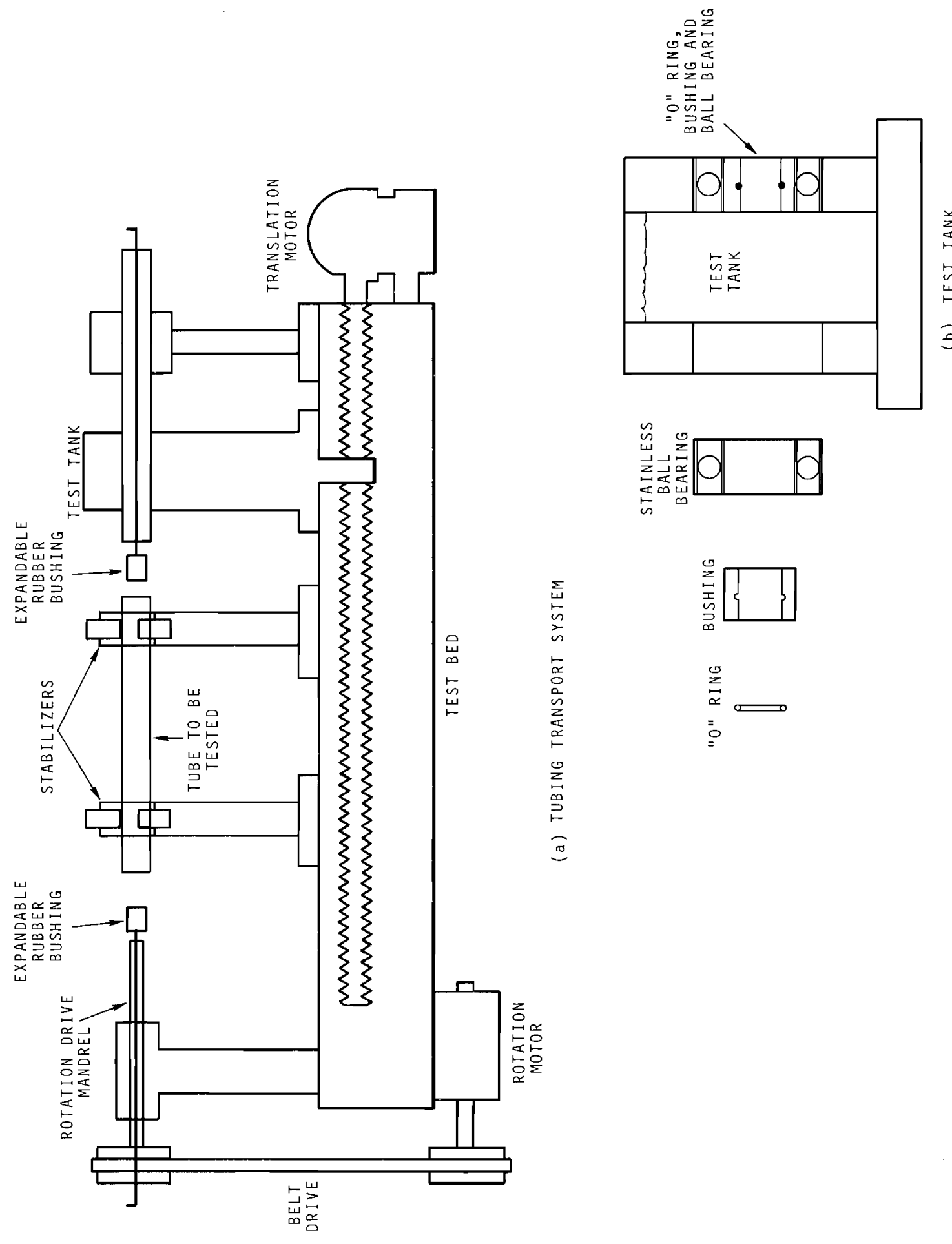

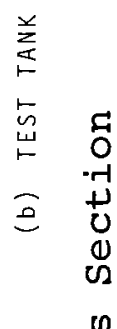

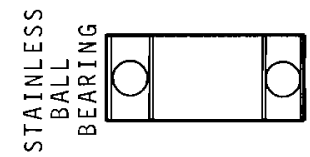

0
0
0
$u$

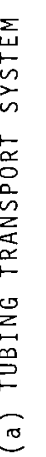

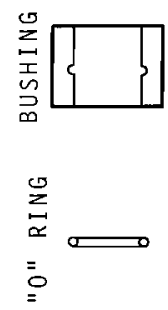

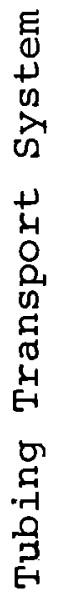

孚 


\section{DESCRIPTION OF ULTRASONIC TECHNIQUE}

An ultrasonic pulse-echo technique was used to inspect the cladding. Two transducers were used, one oriented to detect transverse defects, and the other oriented to detect axial defects as illustrated in Figure 4.

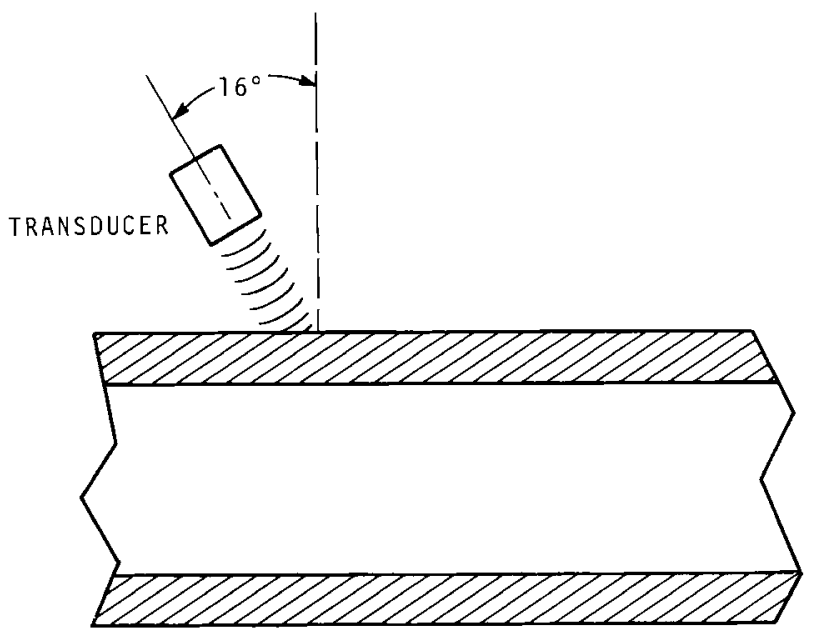

TRANSVERSE TEST

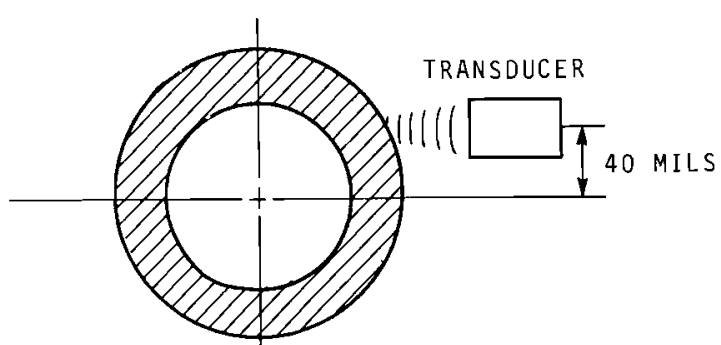

AXIAL TEST

\section{FIGURE 4. Ultrasonic Transducer Positions}

Initially, numerous different types of transducers and modes of ultrasonic wave propagation were investigated. The best results were obtained with a round, unfocused transducer in the transverse test, and a medium spherically focused transducer in the axial test. The complete testing parameters are given in Table 1 . 


\section{TABLE 1. U1trasonic Test Parameters}

\begin{tabular}{|c|c|}
\hline Transverse Test Transducer & $\begin{array}{l}8 \mathrm{MH}_{\mathrm{z}} \text {, flat-faced } \\
125 \mathrm{mi1} \text { diameter } \\
\text { ceramic }\end{array}$ \\
\hline Axial Test Transducer & $\begin{array}{l}10 \mathrm{MH}_{z} \text {, spherically } \\
\text { focused } \\
\text { ceramic }\end{array}$ \\
\hline Transverse Transducer Angle & $16^{\circ}$ \\
\hline Axial Transducer Offset & $40 \mathrm{mils}$ \\
\hline Pulse Repetition Rate & $6000 \mathrm{pps}$ \\
\hline Tube Rotation & $1450 \mathrm{rpm}$ \\
\hline Relative Tube Translation Rate & $9 \mathrm{in} . / \mathrm{min}$ \\
\hline
\end{tabular}

\section{CALIBRATION STANDARD}

In accordance with the testing specifications (see Appendix A), a calibration standard was fabricated. Notches were induced by the electric-discharge-machining (EDM) method in a defect-free tube. A drawing of the standard and the measured notch depths are shown in Figure 5. A11 notches were specified to be $30 \mathrm{mils}$ long by $5 \mathrm{mils}$ wide. Three different depths, for each orientation and location, was desired for calibration purposes. Since the EDM process is not accurate enough to produce the exact desired depth, a11 notches were replicated and the dimensions measured with a microscope.

\section{QUALITY CONTROL PROCEDURES - AND TECHNIQUES}

A statistical control program was followed throughout the testing of the tubing. The purpose of this program was to verify that the tester precision stayed within known limits.

A prerequisite to the start of the inspection was the knowledge of the tester's short and long term drift. This was determined by inspecting the calibration standard with the tester 5 times in succession at $1 \mathrm{hr}$ intervals over an 


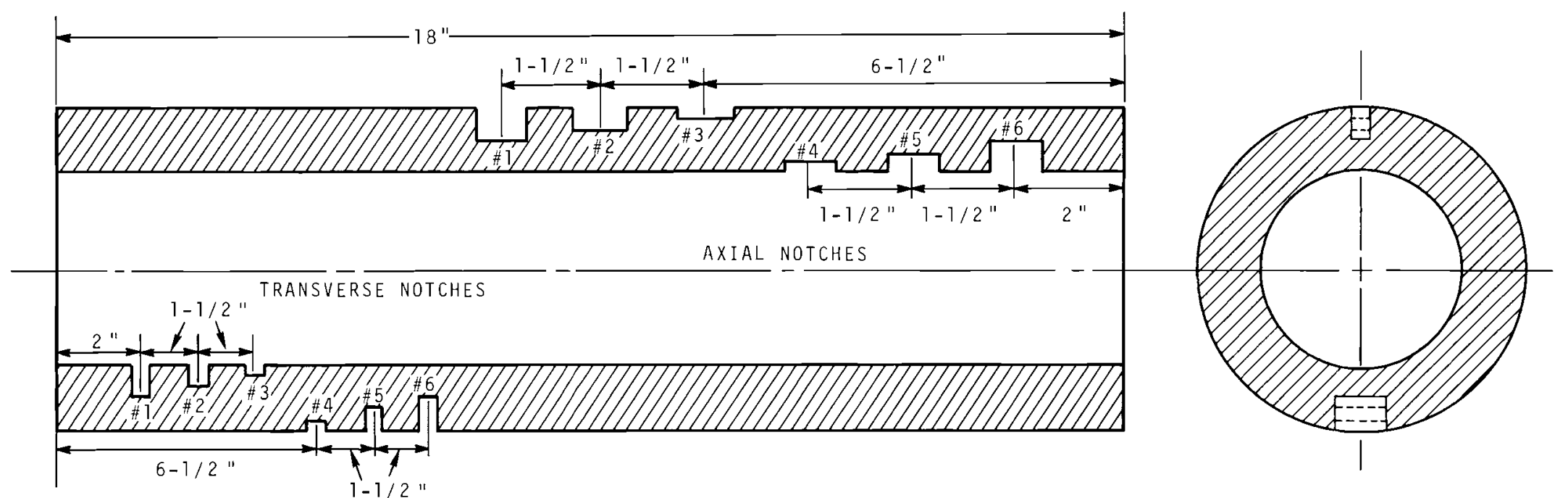

A. CALIBRATION STANDARD

\begin{tabular}{|c|c|c|c|}
\hline NOTCH & DEPTH (MILS) & NOTCH & DEPTH (MILS) \\
\hline TRANSVERSE & 1.73 & AXIAL 1 & 1.20 \\
\hline TRANSVERSE & 2.56 & $A \times I A L 2$ & 2.32 \\
\hline TRANSVERSE & 4.02 & AXIAL 3 & 4.00 \\
\hline TRANSVERSE & 1.02 & AXIAL 4 & 1.65 \\
\hline TRANSVERSE & 1.84 & AXIAL 5 & 2.99 \\
\hline TRANSVERSE & 4.36 & $A \times I A L \quad 6$ & 5.86 \\
\hline
\end{tabular}

B. MEASURED NOTCH DEPTH

FIGURE 5. Calibration Standard Drawing and Measured Notch Depth 
$8 \mathrm{hr}$ period. By use of statistics, the variance of the amplitudes of the tester response from each standard notch was calculated. This was done for both a short-term and long-term basis. The short-term variance was indicative of the precision and the long-term was a measure of the instrument's drift.

A calibration curve was then plotted of the measured notch depths versus the statistical means of the tester response amplitudes, as obtained from the short term variance. This plot, along with the tester precision data, enabled the reject level to be set so that the testing specification could be met.

Control of the tester was maintained throughout the inspection by use of control charts. The testing procedure required that the calibration standard be inspected two consecutive times before initiation of production testing and at approximately each hour thereafter. The range and average for each of the nominal 1 mil deep notches were calculated. These notches were the circumferential inside and outside notches, and the axial inside and outside notches. The average and range for each notch were then plotted on their respective control charts. These values had to be within statistically determined limits or the tester was out of control. An out-of-control situation required corrective action and all tubes had to be retested since the last satisfactory run of the standard.

\section{TESTING PROCEDURE}

Extreme care was exercised during the inspection to prevent damaging the tubes. The tubes were shipped in individual cardboard containers. They remained in these containers until they were inspected. Then only one tube at a time was removed from its container. This extra precaution did not add significantly to the testing time. 


\section{TEST RESULTS}

The $2744 \mathrm{ft}$ of tubing consisted of $3927-\mathrm{ft}$ long tubes. of these, 255 tubes were designated $G$ Lot and the remaining 137 tubes were designated $\mathrm{H}$ Lot.

The $G$ Lot tubes had been fabricated using special procedures and processes. The $H$ Lot tubes had been processed in a normal fashion. The purpose of using the special procedures on G Lot was to determine if a higher yield of nondefective tubes would result. Table 2 summarizes the test results. The $G$ Lot tubes did in fact have fewer defects. In addition to defects, some of the tubes presented a background noise level higher than the reject level. According to the testing specifications, these were also rejects. However, for analysis purposes, a separate category is shown in the table. Again, G Lot had a fewer number in this category. The exact cause of this noise was not definitely determined, although several of these tubes had a larger grain size than the others.

\section{TABLE 2. Test Results}

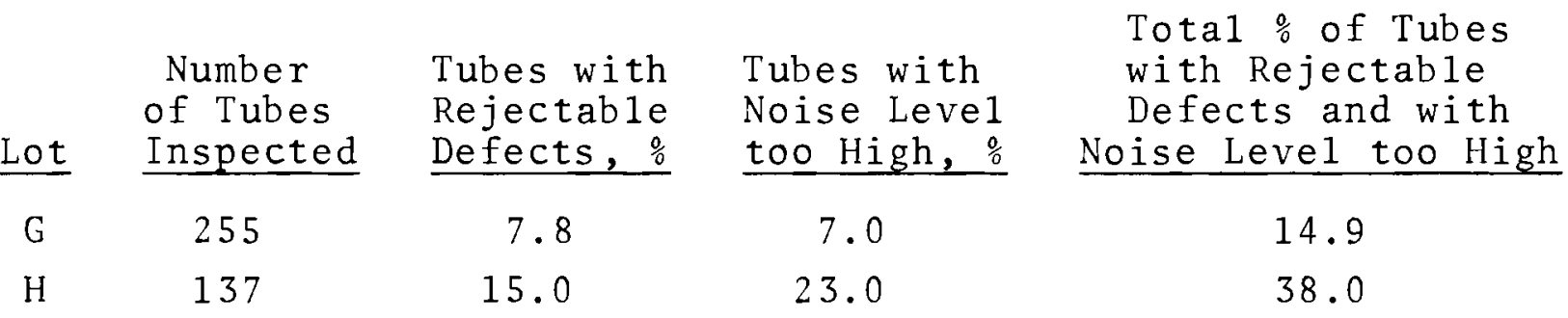

The defects consisted mostly of cracks, laps, and gouges. Figures 6 and 7 show two typical defects. 
BNWL -1359

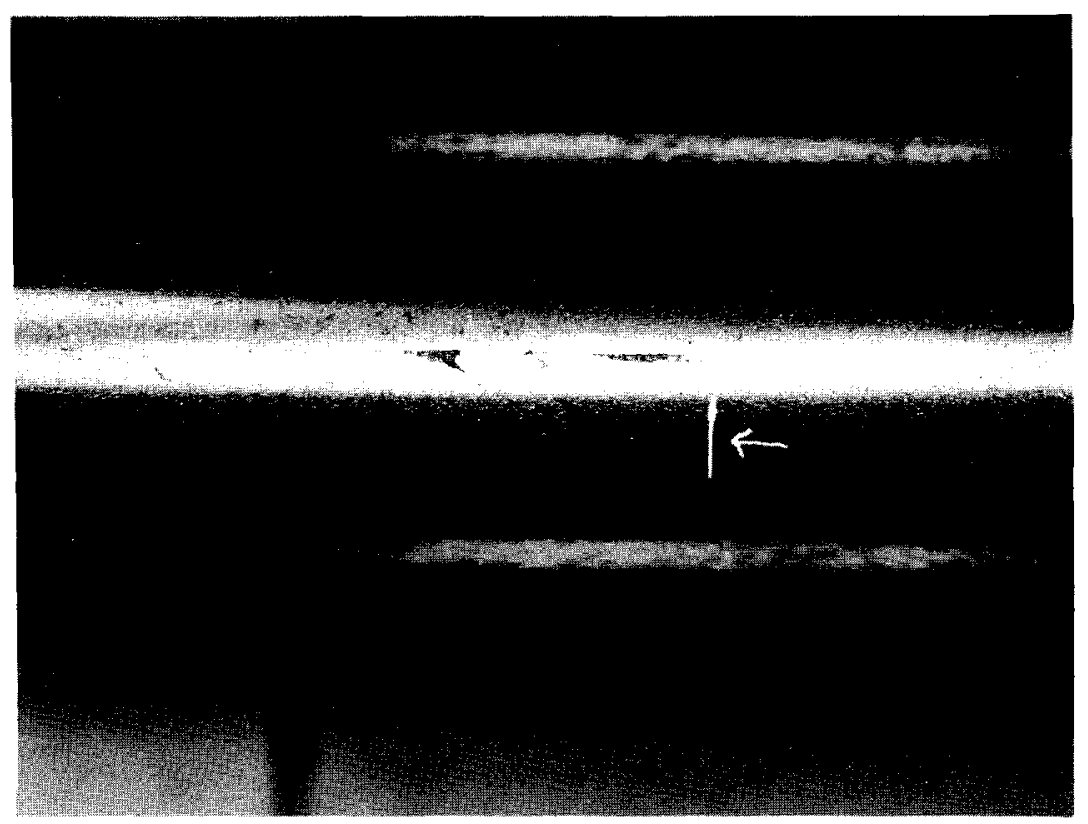

Tube No. G-304

$10 \mathrm{X}$
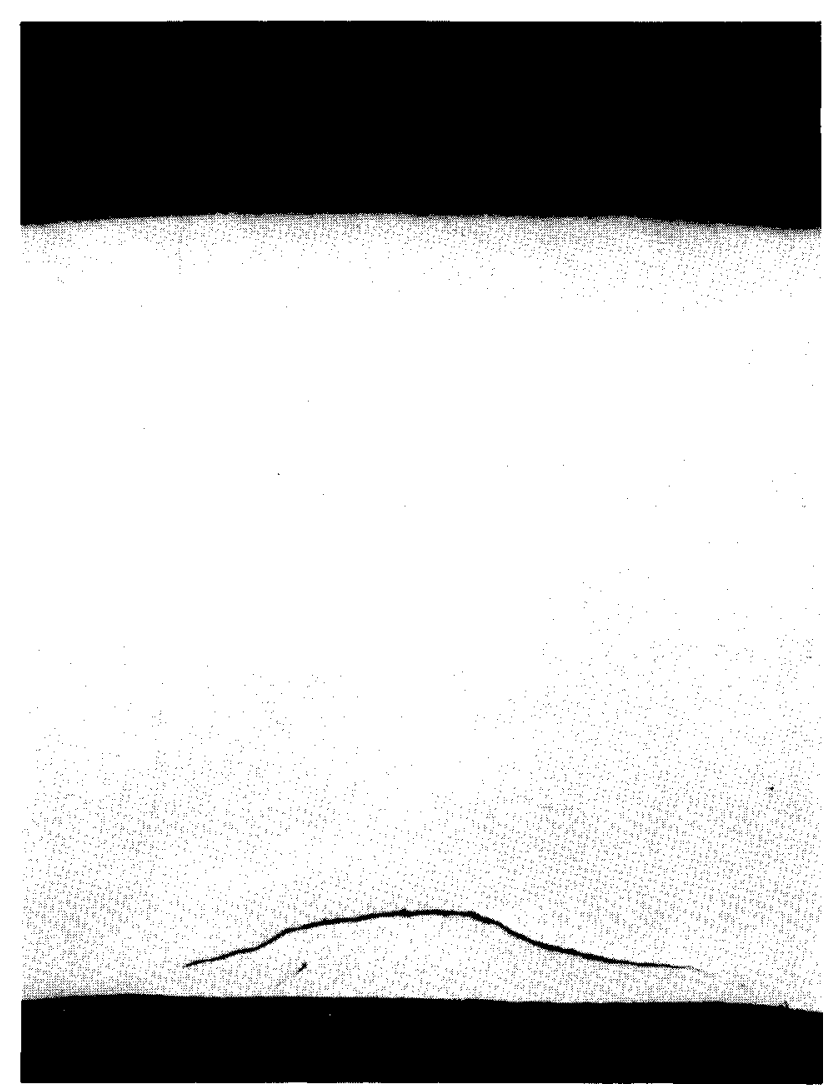

Tube No. G-304 200X

FIGURE 6. Typical Defect from G Lot 
BNWL - 1359

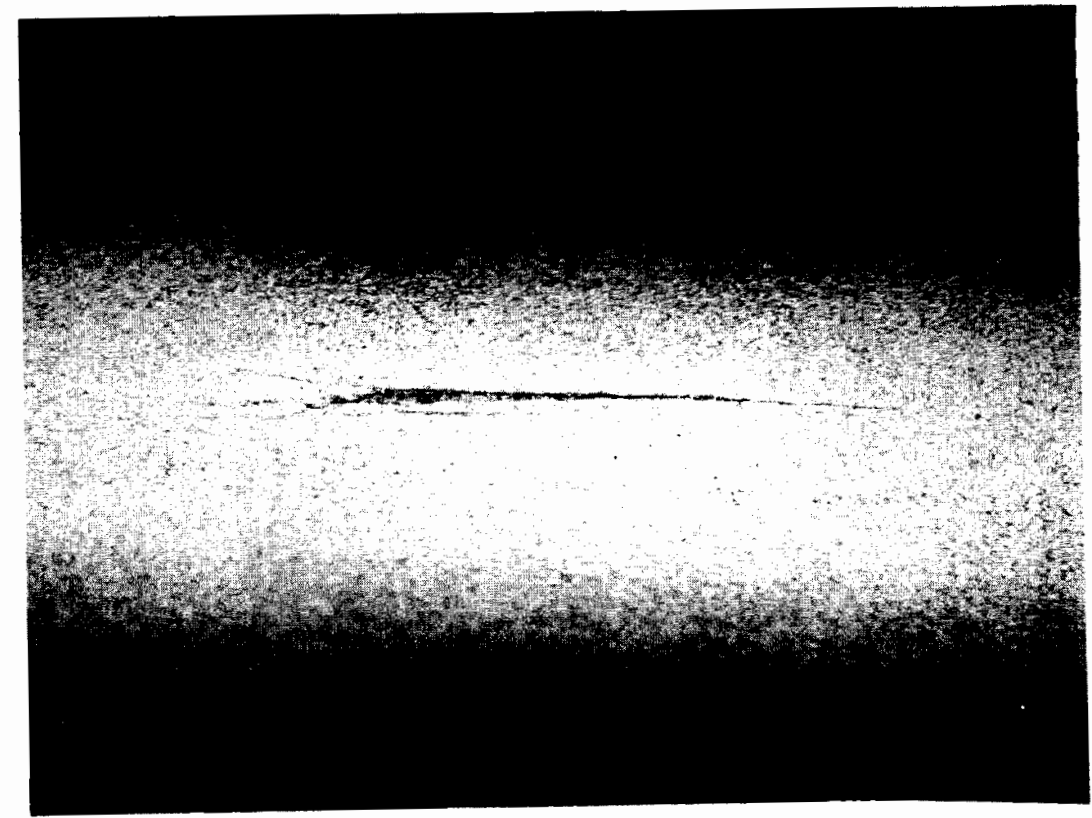

Tube No. $\mathrm{H}-122$
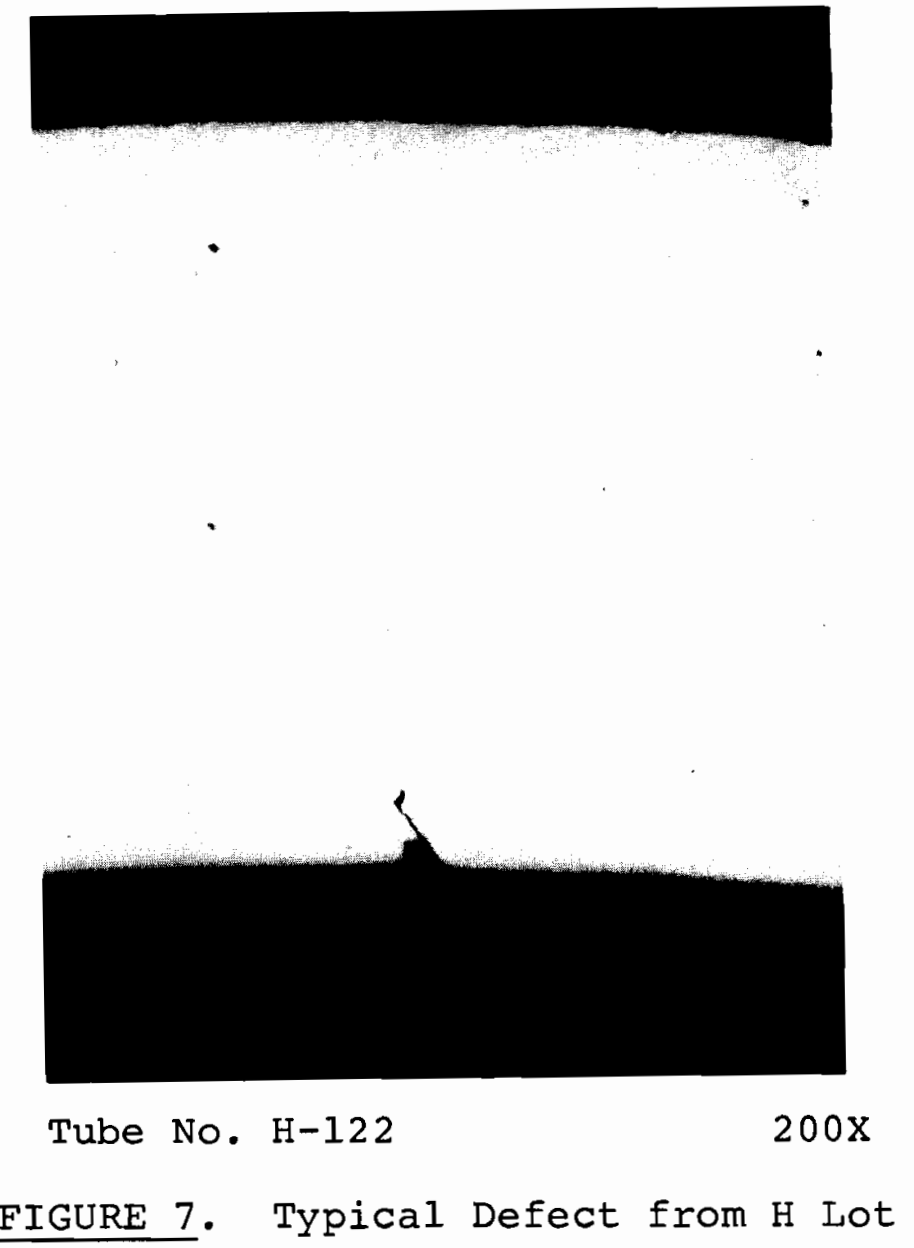


\section{ACKNOWLEDGEMENTS}

The authors express their appreciation to

W. F. Stevenson and A. C. Callen who constructed the statis tical control program, to $R$. J. Lobsinger who represented the tubing user, and to $T$. J. Davis for assistance in some of the circuit design.

\section{REFERENCES}

1. J. Ryden, Jr. Nondestructive Testing of Smazz Diameter Stainzess Steel FueZ Clad Tubing, BNWL-SA-2275. BattelzeNorthwest, Richland, Washington, February 1969. 
,

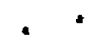


BNWL -1359

APPENDIX A

TESTING AND CLADDING SPECIFICATIONS 


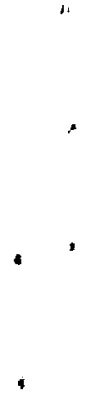




\section{APPENDIX A}

\section{TESTING AND CLADDING SPECIFICATIONS}

\section{TESTING SPECIFICATIONS}

The requirements to be met in the inspection of the cladding are as follows:

- All tubes are to be $100 \%$ inspected.

- A11 defects are to be rejected which produce indications equal to or greater than that produced by electricdischarge-machined notches, oriented circumferentially and axially, on both the inner and outer tube surfaces having dimensions of 0.0012 in. deep by $0.030 \mathrm{in.}$ long by $0.005 \mathrm{in}$. wide. The test system's precision must be controlled to the extent that there is to be a 0.95 certainty that the above sized defects are rejected 95\% of the time.

\section{CLADDING DESCRIPTION}

The cladding was purchased to the following specifications:

- Type 316 stainless stee1

- 0.250 in. $O D \pm 0.001$ in.

- 0.218 in. ID \pm 0.001 in.

- Fully annealed

- Grain size after anneal, less than ASTM 6

- Seven-foot lengths. 

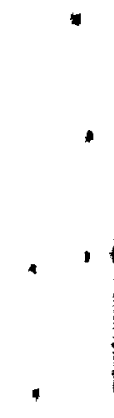


\section{DISTRIBUTION}

No. of

Copies

OFFSITE

1

AEC Chicago Patent Group

G. H. Lee

212

AEC Division of Technical Information Extension

ONSITE-HANFORD

1 AEC Chicago Patent Group

R. K. Sharp (Richland)

1 AEC Richland Operations Office

C. L. Robinson

3 Battelle Memorial Institute

2 RDT Assistant Director for Pacific Northwest Programs

50 Battelle-Northwest

E. R. Astley

R. E. Bardslay

C. A. Bennett

C. A. Burgess

A. C. Callen

T. T. C1audson

R. M. Crawford

G. J. Dau

R. J. Lobsinger

H. N. Pedersen

E. F. Perrizo

H. G. Powers

J. Ryden, Jr.

C. B. Shaw

J. R. Sletager

J. C. Spanner

W. F. Stevenson

J. C. Tverberg

J. B. Vetrano

Technical Information Files

Technical Publications

(2) 


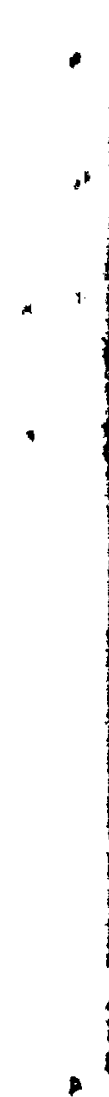

